\title{
MENINGKATKAN KEMAMPUAN KOSA KATA DENGAN MENGGUNAKAN TOTAL PHYSICAL RESPONSE PADA SISWA KELAS II SEKOLAH DASAR SANTA MARIA III MALANG
}

\author{
Irene Trisisca Rusdiyanti \\ Pendididkan Bahasa Inggris, Universitas Kanjuruhan Malang
}

\begin{abstract}
Abstrak
Bahasa Inggris sebagai bahasa International sudah diajarkan di berbagai level pendidikan. Bahasa Inggris tidak asing lagi bagi masyarakat Indonesia pada umumnya, karena bahasa Inggris sudah mulai diajarkan di tingkat taman kanak-kanak sampai dengan perguruan tinggi. Di era globalisaasi ini penguasaan bahasa Inggris sebagai bahasa asing di Indonesia merupakan suatu keharusan, hal ini di karenakan semua ilmu pengetahun serta buku-buku yang menunjang bagi pembelajaran, banyak ditulis dalam bahasa Inggris. Pengajaran bahasa Inggris yang telah dilakukan kadang-kadang membuat siswa siswi masih belum paham dan khususnya dalam pengajaran kosa kata yang nantinya akan dipakai untuk membuat atau menyusun kata menjadi kalimat masih lemah. Salah satunya dikarenakan metode yang digunakan di kelas membosankan dan tidak begitu menarik. Penelitian ini bertujuan untuk meningkatkan kemampuan kosa kata dalam bahasa Inggris dengan menggunakan metode Total Physical Response untuk siswa siswi kelas 2 SDK Santa Maria III Malang sehingga para siswa memiliki kemampuan menguasai kosa kata dengan menggunakan bahasa Inggris dengan baik sesuai porsi mereka. Desain yang akan digunakan dalam penelitian ini adalah penelitian tindakan kelas, dengan berpusat pada sekelompok siswa kelas tertentu. Seperti yang telah dijelaskan oleh Latief (2003:99) penelitian tindakan kelas dilakukan oleh guru untuk mengembangkan strategi dalam proses belajar mengajar di dalam kelas. Penelitian tindakan kelas dapat diterapkan dalam beberapa Siklus/ tahapan, jika hasil yang didapatkan dari tahap 1 belum memuaskan maka peneliti hendaknya merevisi rencana pengajarannya dan melanjutkan pada tahap berikutnya. Setiap tahap dimulai dengan perencanaan, penerapan perencanaan, pengamatan, serta evaluasi proses penerapan metode. Hasil dari evaluasi inilah yang menentukan apakah penelitian perlu dilanjutkan pada tahap berikutnya ataukah tidak. Di sisi lain, Kasbolah (1999:15) berpendapat bahwa penelitian tindakan kelas bertujuan untuk meningkatkan kualitas belajar mengajar di dalam kelas. Adapun kesimpulan yang dapat ditarik adalah penerapan Total Physical Response dalam pengajaran kosa kata dapat meningkatkan kemampuan berbahasa dengan benar baik secara lisan maupun tertulis. Hal ini dapat dibuktikan dari hasil post-test pada cycle 2, siswa siswi memperoleh nilai rata-rata 7.5. Pada cycle 1, para siswa hanya memperoleh nilai rata-rata 6.0. Para siswa juga memberikan komentar bahwa strategy ini banyak memberikan kemudahan bagi mereka, dan guru juga dapat menerapkan strategy ini di masa yang akan datang. Peneliti juga menyarankan agar para guru pengajar bahasa Inggris dapat memperbaiki strategy ini karena strategy pembelajaran dengan menggunakan Total Physical Response sangatlah menyenangkan untuk dilaksanakan di dalam kelas. Bagi peneliti yang lain, metode ini dapat diterapkan untuk pengajaran yang lain. Tujuan utama dari penelitian ini adalah mencoba menyelesaikan permasalahan yang terjadi selama proses belajar mengajar.
\end{abstract}

Kata Kunci: meningkatkan, penguasaan, Total Physical Response.

Kosa kata merupakan komponen penting dari suatu bahasa selain fonologi dan tata bahasa sebab kosa kata merupakan komponen yang mendasar dalam mempelajari ketrampilan ber-bahasa yakni menulis, mendengar, berbicara dan membaca. Apabila seseorang mempunyai kosa kata banyak maka akan bisa berbicara lancar, bisa menumpah- kannya dalam suatu tulisan yang diinginkannya. Sebaliknya kalau seseorang hanya mempunyai sedikit pembendaharaan kata maka orang tersebut juga hanya bisa berbicara dengan kalimat atau kata-kata yang terbatas. Karenanya tidak berlebihan apa bila dikatakan bahwa tata bahasa dan kosa kata merupakan elemen mendasar dari bahasa yang digunakan untuk 
menguasai empat ketrampilan bahasa yakni berbicara, menulis, membaca, dan mendengar (Depdiknas, 2006). Hal ini juga didukung oleh pernyataan Wilkins (2002: 13) bahwa tanpa kosa kata akan sedikit yang bisa disampaikan oleh seseorang.

Mengingat pentingnya kosa kata maka pengajaran mengenai kosa kata (vocabulary) diajarkan pada siswa sejak siswa mempelajari suatu bahasa dalam hal ini bahasa Inggris. Mempelajari kosa kata dalam bahasa Inggris tidaklah mudah karena tulisan dan pengucapannya berbeda apalagi untuk siswa siswi usia sekolah dasar. Selain itu sulitnya mempelajari kosa kata pada anak disebabkan banyaknya pengajar yang masih mengandalkan penerapan metode hafalan. Para siswa diminta menghafalkan kata-kata yang dicatatatkan oleh guru di papan tulis dan itu berlangsung dari waktu ke waktu. Hasil dari sistem belajar seperti itu menyebabkan mahasiswa cepat melupakan apa yang dipelajari. Ada ungkapan yang mengatakan "dengan mendengar saya cepat lupa, dengan melihat saya ingat, dan dengan melakukan sesuatu maka saya mengerti." Ungkapan ini menyatakan bahwa supaya mengerti hendaknya para siswa tidak hanya mendengarkan penjelasan guru saja namun bertindak atau melakukan sesuatu sehingga mereka benar-benar paham akan pelajaran tersebut.

Ada beberapa fakta yang terkait dengan pengajaran kosa kata seperti berikut ini:

1. Kemampuan kosa kata dari para siswa tidak begitu memuaskan. Pada waktu diajar kosa kata, hanya beberapa siswa yang aktif menjawab. Yang lainnya hanya menunggu, mengandalkan temannya. Kalaupun mereka harus menjawab pada saat pengajar menunjuk mereka secara langsung untuk menjawab, mereka membutuhkan waktu yang agak lama, dalam artian tidak spontan dan harus diberi petunjuk misalkan depannya 'w'. Para siswa tidak menjawab pertanyaan karena mereka tidak hafal . Mereka sulit menghafal kata kata dan pada akhirnya biasanya pengajar memperbolehkan mereka melihat buku catatan untuk mengerjakan latihan.

2. Banyak siswa yang tidak memenuhi nilai minimal yang ditargetkan yakni 70 .

Melihat kenyataan bahwa kemampuan kosa kata mereka kurang bagus, maka akan sulit bagi mereka untuk mengembangkan diri pada ketrampilan berbahasa. Situasi di atas mendorong peneliti untuk menyajikan pengajaran kosa kata dengan lebih menarik. Suatu pengajaran yang bisa meningkatkan motivasi siswa dalam mempelajari dan membuat mereka lebih aktif di dalam kelas sehingga mereka bisa mempunyai kosa kata lebih banyak.

Menemukan suatu strategi dalam pengajaran kosa kata di kelas ini tidaklah mudah namun akhirnya Total Physical Response merupakan suatu strategi yang pantas dicoba karena belajar kosa kata tidak berarti harus dengan cara menghafal kata kata yang dicatat di papan tulis saja. Pengajaran kosa kata merupakan seni menolong siswa untuk mempunyai banyak kata dalam bahasa Inggris sedikit demi sedikit dan memberi mereka kegiatan atau aktifitas yang membuat pengajaran menjadi lebih menarik.

\section{Tujuan Penelitian}

Penelitian ini bertujuan untuk meningkatkan kemampuan kosa kata dalam bahasa Inggris dengan menggunakan Total Physical Response untuk siswa siswi kelas 2 SDK Santa Maria Malang. Diharapkan para siswa kelas dua di sekolah Dasar tersebut akan memiliki kemampuan kosa kata dengan menggunakan bahasa Inggris dengan baik. 


\section{Manfaat Penelitian}

Penelitian ini akan bermanfaat untuk meningkatkan kemampuan para siswa dalam hal kosa kata dengan menggunakan bahasa Inggris, selain itu hasil dari penelitian ini akan bermanfaat bagi guru sebagai referensi untuk memahami proses belajar mengajar di sekolah dasar yang bisa dimasukkan dalam mata kuliah EYL (English for Young Learners), sehingga hasil dari penelitian ini dapat bermanfaat untuk menambah khasanah keilmuan serta menjadi referensi bagi dosen, guru dan mahasiswa jurusan Pendidikan Bahsa Inggris pada khususnya dan bagi pembaca pada umumnya.

\section{Metode Penelitian}

Penelitian ini menggunakan metode PTK atau Penelitian Tindakan Kelas dengan tujuan untuk memeriksa atau mengecek bagaimana Total Physical Response bisa meningkatkan kemampuan kosa kata para siswa kelas dua sekolah dasar khususnya di SDK Santa Maria III Malang. Kasbolah dan Sukarnyana (2009:9) menyatakan bahwa tindakan penelitian dilakukan di dalam kelas untuk memperbaiki kualitas proses pengajaran supaya proses pengajaran menjadi lebih efektif.

Dalam melakukan penelitian, peneliti dibantu oleh seorang kolaborator yang masingmasing mempunyai tugas atau peranan yang berbeda. Peneliti mengajar siswa dengan menggunakan Total Physical Response untuk meningkatkan kemampuan siswa dalam bertata bahasa sedangkan kolaborator mengamati proses belajar mengajar.

Model penelitian tindakan kelas yang digunakan dalam penelitian ini mengikuti model milik Kemmis \& Taggart (1988:78) yang memiliki empat langkah yakni (1) perencanaan tindakan, (2) pelaksanaan tindakan, (3) pengamatan, dan (4) refleksi. Seandainya siklus pertama gagal atau tidak sesuai dengan kriteria yang ditetapkan maka perencanaan akan diperbaiki dan melakukan siklus ke dua.

Penelitian ini dilakukan terhadap para siswa kelas dua SDK Santa Maria III Malang. Sekolah ini berada di Jalan Markisah no 6 Malang, Jawa Timur. Semua siswa di kelas ini merupakan subyek penelitian.

Kelas ini dipilih sebagai subyek penelitian karena beberapa alasan. Alasan yang pertama karena kebanyakan mahasiswa di kelas ini kurang aktif. Yang ke dua, Total Physical Response belum pernah diterapkan dalam pembelajaran kosa kata di kelas ini. Yang ke tiga, sebagai seorang pengajar peneliti antusias untuk melakukan inovasi demi membantu para siswa meningkatkan kemampuan berbahasa Inggris, khususnya dalam hal kosa kata.

\section{Prosedur Penelitian}

Penelitian ini menggunakan model penelitian tindakan kelas kolaborator yang meliputi (1) persiapan, (2) perencanaan, (3) pelaksanaan, (4) pengamatan pelaksanaan, dan (5) refleksi.

\section{Pra Penelitian}

Hasil dari persiapan penelitian digunakan untuk menyusun perencanaan pada siklus pertama. Pada langkah ini data diambil dari hasil tes harian kosa kata yang sudah dimiliki oleh guru di kelas ini. Data juga didapat dari pengamatan selama proses belajar mengajar berlangsung di kelas ini.

\section{Perencanaan}

Pada tahap ini, yang harus diselesaikan adalah (1) mempersiapkan strategi pengajaran, (2) mempersiapkan materi, dan (3) menyusun kriteria keberhasilan. Dalam penelitian ini, Total Physical Response dipilih sebagai teknik atau strategi pengajaran karena Total Physical Response dianggap bisa mefasilitasi para siswa dalam meningkatkan penguasaan tata bahasa 
mereka. Permainan diseleksi dan kemudian diterapkan berdasarkan topik yang dipelajari mahasiswa hari itu.

Materi yang digunakan diambil dari Speed up 2, yang ditulis oleh Dra. Rita Kurniawan dan Dra. Naning Partini. Total Physical Response digunakan untuk meredam kebosanan pada siswa yang biasanya hanya mengunakan metode hafalan saja. Cara pembelajaran dengan menggunakan strategi ini adalah Guru memilih atau menyeleksi kata-kata yang akan diperagakan. Misalnya kata kerja "makan, minum, tidur, berdiri," dan sebagainya. Guru memberi arahan atau perintah kepada siswa dengan menggunakan kalimat-kalimat yang sederhana sehingga siswa bisa menangkap arahan tersebut.

Kemudian Guru membuat gerakan untuk kosa kata yang dipelajari kepada para siswa. Gerakan tersebut dimaksudkan untuk memperkenalkan kosa kata. Contohnya apabila guru mengatakan "sleep" maka guru juga menggunakan gerakan "tidur." Kemudian guru dan siswa melakukan gerakan bersama-sama. Awalnya guru memberikan kosa kata dan gerakan yang selalu berurutan. Kemudian setelah diperagakan beberapa kali, kosa kata tersebut diacak. Guru memberikan kata secara lisan dan siswa memperagakan kata tersebut dengan gerakan.

Setelah kosa kata tadi diperagakan dalam gerakan beberapa kali dan siswa sudah paham dan hafal, maka guru meminta mereka menghafalkan kosa kata tanpa gerakan. Mereka menghafalkan kosa kata tersebut secara lisan.

Setelah guru merasa bahwa para siswa sudah paham dengan 3 (tiga) kosa kata yang diajarkan, maka guru menambah kosa kata yang lain. Guru selalu mengawali dengan gerakan pada saat memperkenalkan kosa kata berikutnya. Gerakan-gerakan tersebut diperagakan sampai guru merasa bahwa para siswa hafal kosa kata yang diajarkan. Sama seperti yang dilakukan sebelumnya, apabila para siswa sudah terbantu dengan gerakan, maka guru bisa menghilangkan gerakan dan meminta siswa menghafalkan kosa kata tersebut secara lisan.

Setelah para siswa sudah hafal, maka sekarang giliran mereka untuk saling memberi perintah sebagai latihan. Jadi bukan lagi guru yang menjadi model. Salah seorang siswa menghafalkan beberapa kosa kata. Kemudian dia maju dan mengatakan kosa kata yang harus diperagakan oleh siswa yang lain.

Kriteria keberhasilan disusun untuk mengetahui apakah pengajaran berhasil atau tidak. Berikut ini adalah kriteria keberhasilan yang berkaitan dengan pengajaran kosa kata dengan menggunakan Total Physical Response:

1. Pengajaran dinyatakan berhasil apabila $75 \%$ dari siswa mendapatkan nilai 70 .

2. siswa turut aktif dalam proses pembelajaran dengan kriteria siswa mudah memahami materi yang disampaikan oleh pengajar dan bisa menjawab serta menyelesaikan soalsoal yang diberikan oleh pengajar.

Apabila hasil dari penelitian nanti sesuai dengan kriteria keberhasilan, maka penelitian diakhiri.

\section{Pelaksanaan}

Pelaksanaan merupakan perwujudan dari apa yang sudah direncanakan. Dalam pelaksanaan peneliti berperan sebagai pengajar sedangkan kolaborator bertindak sebagai pengamat. Dalam penelitian ini, penggunaan Total physical Response dalam pengajaran kosa kata dilakukan selama empat pertemuan yakni tiga pertemuan untuk pembelajaran dengan Total Physical Response dan satu pertemuan berikutnya untuk mengadakan tes. Tes diadakan pada akhir siklus.

\section{Pengamatan}

Pengamatan adalah proses pengambilan data mengenai semua aspek dan kejadian yang berlangsung selama penerapan teknik yang 
sudah ditentukan. Tujuan dari pengamatan adalah mengamati apakah penerapan strategi yang dilakukan di dalam kelas mengatasi permasalahan atau tidak.

$$
\text { Peneliti mempersiapkan lembar }
$$
observasi, lembar catatan tambahan, dan kuesioner. Lembar observasi digunakan untuk mengumpulkan data mengenai kegiatan pengajar dan siswa selama proses belajar mengajar. Lembar tersebut terdiri dari keterlibatan siswa, kegiatan siswa selama proses belajar, dan performa pengajar.

Catatan tambahan (field notes) merupakan gambaran tertulis dari proses belajar mengajar. Catatan ini digunakan untuk mengumpulkan data yang tidak tercatat di lembar observasi seperti apa yang didengar, yang dilihat dirasa, dan dialami oleh pengamat. Alasan untuk menggunakan catatan ini adalah untuk mengantisipasi kemungkinan hilangnya data yang penting selama pelaksanaan teknik baru.

\section{Data Analisis dan Refleksi}

Bagian ini meliputi analisis data dengan rumus dalam menganalisis data dan refleksi. Dalam menganalisis data, peneliti menggunakan dua macam data yakni data kualitatif dan kuantitatif. Data kuantitatif diambil dari kuesioner dan hasil tes, sedangkan data kualitatif diambil dari lembar observasi dan catatan tambahan.

Untuk menganalisa data yang sudah terkumpul, dilakukan prosedur yakni mengklasifikasi data dan menyimpulkan data.

\section{Klasifikasi Data}

Data diambil dari sumber-sumber yang berbeda. Data yang diambil dari hasil tes yang diberikan setelah siklus berakhir dan data dari kuesioner digolongkan sebagai data kuantitatif sementara data yang diambil dari hasil pengamatan dan catatan tambahan digolongkan sebagai data kualitatif.

\section{Penyimpulan Data}

Penyimpulan data dilakukan setelah mengevaluasi dan menginterpretasi data. Dalam hal ini ada dua kesimpulan yakni kesimpulan pada setiap siklus dan kesimpulan akhir. Kesimpulan pada setiap siklus menentukan perlu tidaknya diadakan siklus berikutnya sementara kesimpulan akhir secara eksplisit menggambarkan model pengajaran kosa kata yang sudah diperbaiki dengan menggunakan Total Physical Response.

\section{Refleksi}

Dalam melakukan refleksi peneliti dan kolaborator mendiskusikan pelaksanaan dan pengamatan selama proses belajar mengajar. Aspek yang paling penting yang harus diperhatikan oleh peneliti adalah: pelaksanaan dari apa yang sudah direncanakan, (2) kelemahan dan masalah yang muncul selama proses belajar mengajar, dan (3) perbaikan yang dicapai oleh para mahasiswa.

Aktifitas utama dalam langkah ini adalah membandingkan hasil pengamatan dan kriteria keberhasilan yang ditentukan. Hasil refleksi digunakan sebagai informasi untuk mempertim-bangkan tindakan berikutnya. Apabila hasil dari refleksi dalam suatu siklus menunjukkan bahwa hasil tidak memenuhi kriteria yang telah ditentukan, maka harus melakukan rencana kembali dan menerapkannya pada siklus selanjutnya.

\section{Instrument atau Alat Pengumpulan Data}

Ada empat instrumen yang dipakai dalam penelitian ini yakni kuesioner, tes, lembar pengamatan, dan catatan tambahan atau field notes. Kuesioner dibagikan ke siswa untuk mengetahui tanggapan mereka. Sedangkan tes diberikan untuk mengetahui pencapaian siswa. Tes diberikan pada saat siklus berakhir. 


\section{Kuesioner}

Kuesioner dibagikan untuk mendapat informasi mengenai tanggapan siswa terhadap tehnik pengajaran yang diterapkan. Ada sepuluh pertanyaan yang diberikan pada siswa dan dalam kuesioner tersebut terdapat dua pilihan Ya (Y) dan Tidak (T).

\section{Tes}

Tes kosa kata digunakan untuk mengidentifikasi apakah para siswa sudah membuat kemajuan dalam pembelajaran. Tes dibuat oleh pengajar dan tes yang diberikan sesuai dengan topik yang sudah dipelajari oleh para siswa. Tes kosa kata diberikan untuk mengukur pencapaian siswa mengenai materi yang sudah dipelajari. Tes yang diberikan berisi 20 soal. Pemberian tes dilakukan setelah siklus berakhir.

\section{Lembar Observasi}

Lembar observasi digunakan untuk mendapatkan data mengenai kegiatan siswa dan pengajar selama proses belajar mengajar. Aspekaspek pengajar yang diamati adalah cara memfasilitasi strategi atau Total Physical Response di dalam kelas, menjawab pertanyaan siswa, dan sebagainya. Bagi para siswa, observasi meliputi kegiatan dalam malakukan tugas, menjawab pertanyaan, dan sebagainya.

\section{Catatan Tambahan atau Field Notes}

Catatan ini mengumpulkan data yang tidak ada dalam lembar observasi. Alasan penggunaan catatan tambahan adalah mengantisipasi kemungkinan hilangnya data penting selama kegiatan belajar mengajar dengan menggunakan Total Physical Response.

\section{Hasil Dan Pembahasan}

\section{Hasil}

Hasil dari penerapan penelitian tindakan kelas ini didasarkan pada penerapan Total Physical Response serta didukung oleh respon siswa dalam kuesioner. Hasil penelitian ini sekaligus juga menjawab pertanyaan yang diformulasikan dalam rumusan masalah pada bab 1. Selama penerapan penelitian pada siklus 1 dan siklus 2 peneliti menggunakan topik: "Activities" yang dibahas dalam penerapan Total Physical Response. Hal ini juga didukung oleh respon siswa tentang penerapan Total Physical Response selama pembalajaran kosa kata, selain itu hasil penelitian ini juga membahas masalah yang muncul selama penerapan Total Physical Response pada pengajaran kosa kata.

\section{Siklus I}

Nilai rata-rata yang diperoleh oleh siswa pada tes harian adalah 5.3. Atas dasar itu maka peneliti menerapkan Total Physical Response sebagai metode untuk meningkatkan kemampuan siswa dalam pengajaran kosa kata. Siklus 1 dilaksanakan pada tanggal 2 Agustus 2013 - 30 Agustus 2013. Dan dilaksanakan melalui empat tahapan; perencanaan, penerapan, pengamatan, serta evaluasi proses penerapan Total Physical Response. Dalam setiap tatap muka dilaksanakan selama 80 menit, pertemuaan pertama dilaksanakan tanggal 2 Agustus 2013, pertemuan kedua tanggal 9 Agustus 2013, dan pertemuan yang ke tiga dilaksanakan pada tanggal 23 Agustus 2013. Adapun hasil dari penelitian ini dapat digambarkan pada siklus dibawah ini:

\section{Perencanaan I}

Dari hasil analisa masalah, peneliti menemukan bahwa interaksi antara pengajar dan siswa sangatlah rendah. Banyak siswa passive. Mereka asyik dengan topik pembicaraan mereka sendiri, serta tidak memperdulikan penjelasan pengajar. Berdasarkan pengamatan ini, peneliti berencana menerapkan penelitian tindakan kelas untuk meningkatkan interaksi didalam kelas melalui strategi Total Physical Response.

\section{Penerapan I}

Pada tahap ini diperlukan penjelasan detail tentang penerapan strategi Total Physical Response. Pada proses belajar mengajar, 
pengajar menerapkan metode membuka dan menutup pelajaran, sebagai proses pengenalan materi, kegiatan inti, dimana pada tahap ini siswa mulai membahas materi yang yang sudah disiapkan oleh peneliti. Peneliti menggunakan 4 kali pertemuan dalam tahap ini. Pertemuan 1 sampai 3 untuk penjelasan meteri dan penerapan strategi Total Physical Response dan pertemuan ke empat digunakan untuk pemberian tes guna mengukur keberhasilan strategi ini.

\section{Pengamatan}

Pada siklus 1 peneliti memusatkan pada pengamatan di dalam kelas secara umum. Interaksi selama penerapan Total Physical Response tidak terekam secara detail.

Berkaitan dengan masalah yang diformu-lasikan pada penelitian ini, maka peneliti dapat menyimpulkan beberapa fenomena selama penerapan Total Physical Response pada pengajaran kosa kata. Pada pertemuan pertama para siswa antusias untuk maju dengan mengankat tangan namun pada waktu di depan kelas mereka masih tampak bingung. Sebaiknya guru benar-benar menjelaskan secara detail kalau perlu lebih dari satu kali apa yang harus dilakukan para siswa.

Pada pertemuan yang kedua, pengajar meminta para siswa untuk lebih banyak latihan. Latihan ini berguna untuk mencermati apakah para siswa sudah benar-benar mengerti akan materi pada hari itu. Selama penerapan Total Physical Response para siswa dan pengajar melakukan interaksi dengan bertanya, menjawab pertanyaan serta memberikan komentar.

Pada pertemuan yang ketiga, peneliti menemukan fenomena yang berbeda pada penerapan Total Physical Response. Pada dasarnya ada banyak kesempatan bagi pengajar dan siswa untuk melakukan interaksi selama penerapan Total Physical Response. Interaksi ini dapat dilakukan melalui latihan yang diberikan oleh pengajar, memberikan informasi, serta komunikasi langsung untuk memecahkan permasalahan yang terjadi selama penerapan Total Physical Response. Pada penerapan metode ini para siswa lebih mempunyai tanggung jawab dalam belajar serta berusaha untuk memahaminya.

Pada pertemuan yang ke empat peneliti menerapkan post test. Pengajar membagikan soal kepada para siswa dan siswa mengerjakan soal yang diberikan. Dari sini dapat diketahui bahwa beberapa siswa mengerjakan dengan tersenyum namun beberapa siswa masih nampak ragu-ragu dalam menentukan jawaban yang benar.

\section{Evaluasi Penerapan Total Physical Response}

Dari pengamatan yang telah dilakukan, peneliti menemukan beberapa permasalahan yang terjadi dari penerapan Total Physical Response. Masalah tersebut antara lain adalah siswa tidak mengikuti penerapan teknik dengan baik. Mungkin karena terlalu antusias maka para siswa waktu diminta siapa yang mau maju angkat tangan, mereka tidak hanya angkat tangan namun angkat tangan sambil bersuara 'saya, saya.' Maka kelas menjadi ribut. Setelah mereka nagkat tangan dengan bersuara, masalah lain yang timbul adalah bahwa pada saat mereka sudah di depan kelas, beberapa dari mereka masih tidak tahu yang harus dilakukan. Maka pengajar harus member instruksi lagi kepada mereka. Hal ini dikarenakan para siswa belum terbiasa dengan tehnik Total Physical Response.

Adapun hasil dari post test diperoleh hasil nilai rata-rata siswa adalah 6.0. Hal ini menunjukkan bahwa kemampuan siswa dalam pengajaran kosa kata masih belum mencapai criteria keberhasilan.. Berdasarkan hasil yang diperoleh pada siklus pertama, maka peneliti memutuskan bahwa penerapan Total Physical Response ini masih belum mencapai kriteria keberhasilan yang telah ditentukan, sehingga 
peneliti memutuskan untuk melanjutkan pada siklus yang kedua.

\section{Siklus II}

Berdasarkan hasil dari penerapan Total Physical Response pada siklus 1 diperoleh nilai rata-rata siswa 6.0 maka penelitian ini perlu dilanjutkan pada siklus yang kedua.

Siklus kedua dilaksanakan pada $6-27$ September 2013. Masih sama dengan penerapan pada siklus 1, pada siklus yang kedua ini juga menerapkan tahapan dalam penelitian tindakan kelas, yaitu: merubah perencanaan, penerapan yang terdiri dari tiga pertemuan dan satu pertemuan untuk post test, pengamatan, serta evaluasi hasil pengamatan. Peneliti mencoba berkonsultasi dengan guru untuk memperbaiki penerapan Total Physical Response.

\section{Penerapan II}

Penerapan Metode ini dilaksanakan dalam 3 pertemuan dan 1 pertemuan untuk pemberian post test. Kegiatan inti dimulai dengan mengulangi materi dengan melakukan gerakan bersama-sama. Kemudian pengajar memberikan materi kepada para siswa mengenai topik 'activities' dengan kosa kata yang berkenaan dngan kata kerja kepada para siswa.

\section{Pengamatan II}

Pada pertemuan pertama, para siswa diberikan materi mengenai topik aktifitas dan diberi latihan. Para siswa diberikan kesempatan selama beberapa menit untuk menghafalkan kata-kata kerja yang akan diinstruksikan kepada teman waktu di depan kelas.

Interaksi antara pengajar dan siswa terjadi ketika siswa mengalami kesulitan dalam membuat gerakan dan mengexpresikan ide mereka dalam bahasa Inggris.

Pada pertemuan yang kedua siswa lebih percaya diri untuk maju ke depan kelas dan membutuhkan waktu yang lebih sedikit untuk memikirkan kata kerja yang akan diinstruksikan kepada teman. Siswa nampak lebih aktif dan terarah daripada sebelumnya. Interaksi antara pengajar dan siswa terlihat lebih natural. Pengajar lebih banyak bahasa Inggris daripada pertemuan-pertemuan sebelumnya dalam proses belajar mengajar.

Pada pertemuan ketiga, siswa sudah lebih terarah dan tertib dalam mengikuti tahapan Total Physical Response. Siswa memberi instruksi dengan hati-hati dan teliti. Pada pertemuan ke empat, siswa mengerjakan post test siklus 2. Dalam mengerjakan test ini siswa sudah tidak memerlukan banyak bimbingan dan instruksi dari pengajar. Siswa dapat mengerjakan soal-soal yang diberikan pengajar dengan lancar dan tanpa ragu-ragu lagi. Hal ini menunjukkan jika siswa lebih memiliki kepercayaan diri dalam mengerjakan test yang diberikan. Hasil dari test kedua ini menunjukkan adanya peningkatan kemampuan mahasiswa dalam kosa kata bahasa Inggris.

\section{Evaluasi Hasil Pengamatan II}

Dari hasil pengamatan didapatkan kesimpulan bahwa penerapan Total Physical Response memberikan kesempatan kepada siswa untuk berinteraksi dengan siswa yang lain dan juga dengan pengajar. Interaksi ini sangat diperlukan untuk membuat siswa lebih percaya diri, tidak takut, dan lebih baik dalam penguasaan kosa dengan menggunakan bahasa Inggris. Walupun mereka tidak langsung memahami topik yang diberikan, mereka dapat dengan mudah dan rileks bertanya dan berkomunikasi dengan pengajar.

Selain itu penerapan metode ini dapat membuat siswa lebih aktif dan tidak lagi pasif dalam proses belajar mengajar. Penerapan metode ini membuat siswa lebih aktif untuk menggali pengetahuan dan pengalaman. Selain itu, penerapan Total Physical Response dapat meningkatkan kemampuan siswa dalam 
memahami kosa kata bahasa Inggris dengan mudah. Hal ini dapat dibuktikan dari hasil post test siswa yang diperoleh hasil rata-rata 7.5, sehingga peneliti memutuskan untuk tidak melanjutkan siklus selanjutnya.

\section{Pembahasan}

\section{Hasil Questionnaire}

Tanggapan siswa dalam penelitian ini menunjukkan pendapat mereka mengenai penggunaan Total Physical Response dalam pembelajaran kosa kata. Kuesioner berisi beberapa variabel yang diukur yakni: 1) motivasi belajar, 2) hasil belajar, 3) penyelesaian tugas, and 4) hubungan sosial.

\section{(1) Motivasi belajar}

Variabel pertama ini mendapat tanggapan yang memuaskan dari mahasiswa. Ini bisa dilihat dari keempat pernyataan yang berkenaan dengan hal tersebut. Pernyataan "Saya merasa senang belajar kosa kata dengan menggunakan Total Physical Response" dan pernyataan " Dengan Total Physical Response belajar kosa menjadi lebih menarik dan tidak membosankan "dipilih oleh 45 (100\%) siswa.

\section{(2) Hasil belajar}

Variabel ke dua juga mendapatkan tanggapan yang memuaskan dari siswa. Seratus persen (100\%) siswa mendukung 3 indikator yang ada pada variabel ini. Ketiga indikator tersebut adalah: 1) mudah mempelajari hal baru, 2) mengingat pelajaran dengan lebih mudah, 3) menimbulkan rasa percaya diri.

\section{(3) Penyelesaian Tugas}

Variabel penyelesaian tugas dengan indikator "dengan menggunakan Total Physical Response, siswa lebih bersemangat menyelesaikan tugas" mendapat tanggapan yang baik pula dari mahasiswa. 39 siswa menyatakan ya dengan pernyataan tersebut, 6 siswa memilih tidak.

\section{(4) Hubungan Sosial}

Variabel hubungan social dengan indikator "penggunaan Total Physical Response bisa meningkatkan hubungan social" mendapat tanggapan yang baik pula dari mahasiswa. 40 siswa menyatakan setuju dengan pernyataan tersebut dan 5 siswa memilih tidak.

Masalah yang Dihadapi siswa selama Penerapan Total Physical Response

Permasalahan yang dihadapi mahasiswa, selama penerapan permainan dapat dideskripsikan sebagai berikut:

\section{(1) Ramai}

Suasana kelas dirasa sangatlah ramai karena pengajar memberikan kesempatan kepada siswa untuk maju dengan cara angkat tangan. Namun pada kenyataannya siswa angkat tangan sambil berteriak 'saya, saya.'

\section{(2) Kurangnya Kesiapan Pada Waktu Maju}

Banyak dari siswa yang karena antusias untuk maju maka mereka tidak mempersiapkan kata kerja yang harus diinstruksikan kepada teman. Mereka sungguh senang karena diperbolehkan maju namun sesampai di depan kelas tampak tidak siap.

\section{(3) Masalah Lainnya}

Beberapa siswa menyatakan bahwa mereka tidak dapat membuat gerakan yang variatif seperti teman-temannya sehingga mereka nampak tidak begitu antusias pada waktu diminta maju.

\section{Pendapat siswa dalam Penerapan Total Physical Response}

Menurut pendapat siswa, penerapan Total Physical Response sangatlah bermanfaat dan menyenangkan, akan tetapi ada juga siswa yang merespon kurang antusias dari penerapan strategi ini. 


\section{Respon Positif}

$36 \%$ siswa menyatakan tertarik dengan adanya penerapan Total Physical Response, selain itu $70 \%$ siswa menyatakan metode ini sangatlah sesuai jika diterapkan pada pengajaran kosa kata. Selanjutnya, 33,3\% siswa sepakat bahwa penerapan strategy ini sangatlah menyenangkan dan sebagian besar siswa $(83,3 \%)$ menyatakan setuju jika strategy ini digunakan lagi pada masa yang akan datang.

Siswa menemukan beberapa keuntungan selama penerapan metode Total Physical Response antara lain:

(1) Siswa dapat mengexpresikan idenya secara bebas melalui gerakan.

(2) Siswa dapat memahami berinteraksi dengan teman.

(3) Siswa menemukan pengalaman baru.

(4) Siswa belajar untuk bekerjasama dalam satu group (deret).

(5) Siswa dapat mengembangkan kemapuan berpikir dan kemampuan berbahasa Inggris.

(6) Siswa lebih aktif dalam proses belajar mengajar.

\section{Respon Negatif}

$20 \%$ siswa memberikan tanggapan negative terhadap penerapan metode ini. Mereka berpendapat bahwa penerapan metode ini memiliki beberapa kelemahan, antara lain:

(1) Kelas sangat ramai.

(2) Tidak efektif.

(3) Membuang banyak waktu.

(4) Siswa yang rajin dan pandai mendapat perhatian lebih daripada siswa yang tidak aktif.

\section{Kesimpulan}

Kesimpulan dari penelitian ini didasarkan pada rumusan masalah yang telah diformulasikan sebelumnya. Secara umum dapat ditarik kesimpulan bahwa penerapan Total Physical Response dapat memecahkan perma- salahan yang terjadi. Lebih khusus dapat pula ditarik kesimpulan bahwa dengan penerapan metode ini dapat meningkatkan interaksi antar siswa, interaksi pengajar dan siswa, serta dapat pula memecahkan perma-salahan yang terjadi di kelas, khususnya untuk pengajaran kosa kata dengan menggunakan Total Physical Response.

Berkaitan dengan interaksi antar siswa dalam Total Physical Response, peneliti dapat menyimpulkan adanya peningkatan interaksi positif antar siswa. Hal ini juga meningkatkan partisipasi aktif siswa dalam pengajaran kosa kata. Selanjutnya, strategy ini juga memberikan kesempatan bagi siswa untuk mempraktekkan kemampuan dalam berbahasa Inggris dengan saling member instruksi.

Berkaitan dengan interaksi antara pengajar dan siswa dalam penelitian ini, dapat diketahui bahwa terjadi peningkatan dalam interaksi antar pengajar dan siswa selama penerapan Total Physical Response. Siswa lebih merasa leluasa untuk mengungkapkan kesulitan yang mereka hadapi selama mengikuti pembelajaran kosa kata. Selain itu pengajar dan siswa juga dapat saling berinteraksi tanpa siswa merasa terbebani atau merasa takut. Pengajar lambat laun menggunakan bahasa Inggris yang ditambah porsinya didalam kelas.

Berkaitan dengan masalah yang muncul selama penerapan strategy ini adalah; situasi kelas sangat ramai, kurangnya kesiapan siswa pada waktu maju ke depan kelas, dan siswa merasa kurang kreatif. Akan tetapi masalah ini bisa diatasi dengan memberikan siswa waktu untuk menentukan kata kerja yang akan diinstruksikan dan memperbolahkan siswa membuat gerakan yang sama. Keterbatasan siswa dalam memahami makna dan mengomunikasikan kosa kata dapat terselesaikan dengan penerapan Total Physical Response.

Adapun kesimpulan yang dapat ditarik adalah penerapan Total Physical Response dapat meningkatkan kemampuan penguasaan 
kosa kata bagi siswa. Hal ini dapat dibuktikan dari hasil post-test pada siklus 2, siswa memperoleh nilai rata-rata 7.5. Pada siklus 1 , siswa hanya memperoleh nilai rata-rata 6.0. Siswa juga memberikan pendapat bahwa strategy ini banyak memberikan kemudahan kepada siswa, dan pengajar juga dapat menerapkan strategy ini di masa yang akan datang.

\section{Saran}

Berdasarkan hasil temuan penelitian, peneliti memberikan beberapa saran dengan tujuan untuk meningkatkan kualitas proses belajar mengajar. Saran ini ditujukan bagi pengajar bahasa Inggris khususnya dalam mengajar kosa kata dan peneliti yang lain.

\section{Bagi pengajar}

Bagi pengajar bahasa Inggris, peneliti menyarankan agar para pengajar bahasa Inggris bisa melanjutkan menggunakan aktivitas Total Physical Response. Karena strategy ini dapat diterapkan dengan mudah dan memberikan banyak keuntungan bagi siswa. Selain itu, pengajar harus lebih tegas dan disiplin dalam proses pembelajaran agar suasana kelas dapat terkontrol dengan baik, dan tidak terlalu ramai. Selain itu pengajar harus lebih aktif dan kreatif dalam pelaksanaan metode ini, agar terjadi komunikasi yang baik antara pengajar dan siswa. Peneliti juga menyarankan agar penga- jar dapat memperbaiki strategy ini karena strategy pembelajaran dengan menggunakan Total Physical Response sangatlah menyenangkan.

\section{Bagi Peneliti yang lain}

Bagi peneliti yang lain, metode ini dapat diterapkan untuk pengajaran selain kosa kata. Tujuan utama dari penelitian tersebut adalah mencoba menyelesaikan permasalahan yang terjadi selama proses belajar mengajar.

\section{Daftar Pustaka}

Departeman Pendidikan Nasional. 2006. Standar Nasional Pendidikan Mata Pelajaran Bahasa Inggris Sekolah Menengah Pertama. Jakarta: Depdiknas

Kasbolah, K \& Sukarnyana, I. W. 2009. Penelitian Tindakan Kelas. Malang: Universitas Negeri Malang.

Kemmis, S \& Mc Taggart, R .1988. The Action Research Planner. Sidney: Deakin University.

Latief, Adnan. 2003. Penelitian Tindakan Kelas Pembelajaran Bahasa Inggris. Jurnal Ilmu Pendidikan, Jilid10, No. 2. Juni 2003.

Wilkins, D.A. 2002. Linguistics and Language Teaching. London: Edward Arnold Ltd. 